\title{
Low energy values of fish as a probable cause of a major seabird breeding failure in the North Sea
}

\author{
S. Wanless ${ }^{1, *}$, M. P. Harris ${ }^{1}$, P. Redman ${ }^{2}$, J. R. Speakman ${ }^{2}$ \\ ${ }^{1}$ NERC Centre for Ecology and Hydrology, Banchory Research Station, Hill of Brathens, Banchory AB31 4BW, UK \\ ${ }^{2}$ Aberdeen Centre for Energy Regulation and Obesity (ACERO), School of Biological Sciences, University of Aberdeen,
} Aberdeen AB24 2TZ, UK

\begin{abstract}
Many seabirds in the North Sea feed on lesser sandeels Ammodytes marinus during the breeding season. Unprecedented breeding failures were recorded at many seabird colonies on the east coast of Britain in 2004. We used demographic, dietary and behavioural data from a long-term study of a colony of common guillemots Uria aalge, the most abundant seabird species in the North Sea, to set the 2004 season in context. Birds at this colony showed greatly reduced breeding success and those chicks that did survive left the colony in very poor condition. The main prey item fed to chicks in 2004 was sprat Sprattus sprattus rather than sandeels, and parents increased the amount of time spent foraging, frequently leaving chicks unattended in order to maintain a normal feeding rate. The calculated daily food intake of chicks derived from these values did not differ markedly from previous years and therefore the magnitude of the impact on chick growth and breeding success appeared disproportionately large. However, nutrient analyses of fish collected from birds in 2004 revealed them to be of significantly lower energy value than expected. Poor food quality therefore appeared to be the proximate cause of seabird breeding failure in 2004 giving support to the 'junk-food' hypothesis. Single-prey loaders such as guillemots will be particularly sensitive to reductions in the energy value of food items. The reasons for the poor fish condition in this part of the North Sea are currently unknown, but the results provide further evidence of major changes in the North Sea food web.
\end{abstract}

KEY WORDS: Breeding failure $\cdot$ Energy value $\cdot$ Lesser sandeel $\cdot$ Sprat $\cdot$ Food intake $\cdot$ Predator-prey interactions · Common guillemot · Junk food hypothesis

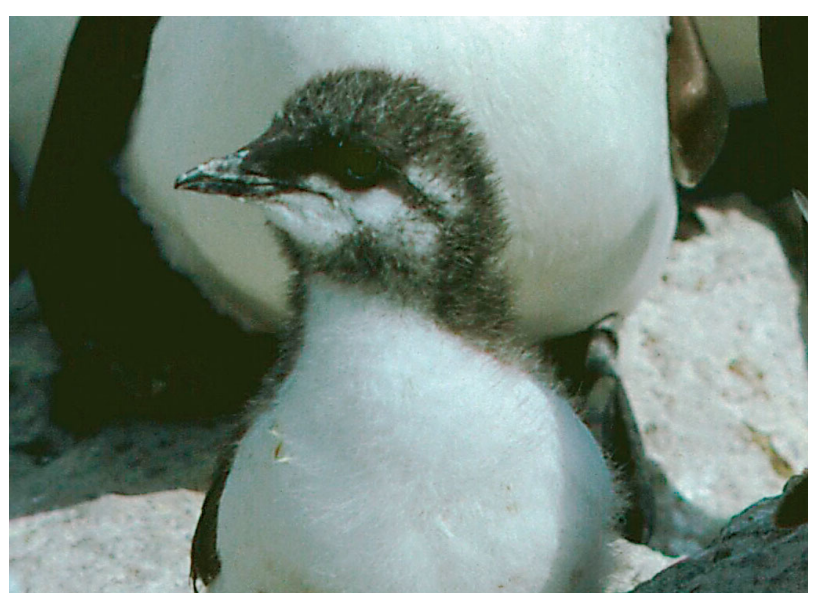

Guillemots on the Isle of May, Scotland, had greatly reduced breeding success in 2004 and those chicks that did survive were severely underweight. Poor food quality was found to be the likely cause of the failures, perhaps due to changes in plankton abundance or distribution.

Photo by Mike Harris

\section{INTRODUCTION}

Many species of seabirds in the North Sea rely heavily on a single species of fish, the lesser sandeel Ammodytes marinus (hereafter 'sandeel'), with which to rear their young (Pearson 1968). In some areas, notably Shetland, there appears to be no alternative high energy prey, and if sandeels are not easily available, breeding is either poor or fails completely (Monaghan et al. 1992, Wright 1996). However, birds that breed further south potentially have alternative pelagic shoaling prey species, notably the energy richsprat Sprattus sprattus (Harris \& Hislop 1978). 
The common guillemot Uria aalge (hereafter 'guillemot') is the most abundant seabird in the North Sea (Mitchell et al. 2004). It is generally regarded as a sandeel specialist catching fish by underwater-pursuit throughout the water column. It is considered to be better buffered against food shortage than some other sandeel specialists such as the black-legged kittiwake Rissa tridactyla and Arctic tern Sterna paradisaea, that catch sandeels at the surface (Monaghan et al. 1992). Breeding success of guillemots (measured to the time that the chick leaves the breeding site) in colonies within the North Sea is usually high, 0.7 to 0.8 young per pair laying (Mavor et al. 2004). However, low success was reported from several colonies in 2003 (Mavor et al. 2004). The situation deteriorated further in 2004 with guillemots in Shetland experiencing almost complete breeding failure and colonies further south in the North Sea having severely reduced success (Mavor et al. 2004, 2005). Here we use demographic, dietary and behavioural data from a long-term study at a colony in SE Scotland to put the 2004 breeding season into perspective and report on analyses of the energy value of the prey that suggest the likely proximate cause of the poor breeding.

\section{MATERIALS AND METHODS}

The study species. The guillemot breeds colonially on sea cliffs and normally members of a pair alternate incubation shifts of the single egg (the invariate clutch) or guard shifts of the chick, to provide continuous protection from predators and adverse weather (details of biology in Ainley et al. 2002). Guillemots are singleprey loaders and thus a successful foraging trip results in the delivery of 1 fish to the chick. Guillemots typically feed 10s of kilometres from the colony, and each adult normally makes only 1 to 3 foraging trips each day, so the size and quality of the fish brought back are likely to be more critical for chick growth and survival compared to multi-prey-loading species including those that bring back food in their stomach. When the guillemot chick is about 3 wk old, a quarter grown, and still flightless, the male parent takes it to sea and continues to feed it for many weeks while it completes its growth. The female continues to visit the nest-site for several weeks, apparently to maintain ownership since good breeding-sites are often in limited supply (Harris \& Wanless 2003).

Field data. The population of guillemots on the Isle of May, Firth of Forth, Scotland, UK ( $56^{\circ} 11^{\prime}$ N, $2^{\circ} 34^{\prime}$ W) has been studied intensively each year since 1981. Details of breeding performance come from standardized daily observations of approximately 1000 indi- vidually numbered nest-sites, including those of ca. 300 uniquely colour-ringed breeding adults (Harris \& Wanless 1988). Each year, samples of chicks ( $\mathrm{n}=300)$ were weighed $( \pm 1 \mathrm{~g})$ with a spring balance. Wing length, measured $( \pm 1 \mathrm{~mm})$ from the bend of the wing to the tip of the longest primary covert, is linearly related to age, but the rate of increase in weight declines substantially near the time that the chick leaves the colony (Hedgren \& Linnman 1979). We therefore used the mean mass of birds with a wing length $\geq 60 \mathrm{~mm}$ (approximating to an age $\geq 17 \mathrm{~d}$ ) as an annual index of chick condition prior to leaving the colony (Harris et al. 1992). Annual estimates of diet composition come from daily records of fish fed to chicks throughout the chick-rearing period. Feeding frequency (number of fish delivered chick ${ }^{-1} \mathrm{~d}^{-1}$ ) and the time that members of a pair spent together after the chick was fed were recorded during standardized dawn-to-dusk watches of 30 to 100 nest-sites in delimited areas (Harris \& Wanless 1985). Fish were identified to species and assigned to small, medium or large size categories that corresponded to age classes of fish. Measurements of fish dropped by adults on the breeding ledges were used to validate the lengths of these categories each year, though this proved impossible in 2004 when virtually all fish brought to the colony were eaten. Instead, fish brought in by Atlantic puffins Fratercula arctica were measured and these measurements agreed well with the few fish collected from guillemots.

Energy determinations. In 2004, sandeels and sprats collected from guillemots and puffins were measured (total length from tip of the snout to the end of the tail) and then frozen for subsequent organic analyses. Fish carried back to the colony by seabirds lose weight due to dehydration (Montevecchi \& Piatt 1987), so all energy values were expressed on a dry weight basis.

Each fish was dried to a constant weight at $60^{\circ} \mathrm{C}$ (dry mass) and the fat extracted using diethyl ether in a soxhlet apparatus (Reynolds \& Kunz 2001). The remaining material was dried, re-weighed (fat-free mass) and put into a muffle furnace at $600^{\circ} \mathrm{C}$ for $10 \mathrm{~h}$ to incinerate the protein. The resulting ash was then weighed to determine the mineral content (mineral mass). All measurements were made on a 4-figure balance and the total fat and protein content of each fish was determined as follows: fat content $(\mathrm{g})=$ dry mass - fat free mass; protein content $(g)=$ fat-free mass - mineral mass. The energy value of each fish was then obtained from the body composition using energy equivalents of $39.6 \mathrm{~kJ} \mathrm{~g}^{-1}$ for fat and $23.7 \mathrm{~kJ} \mathrm{~g}^{-1}$ for protein (Crisp 1971).

The 2004 values for energy determination of whole fish were compared with predicted values using the equations: 


$$
\begin{aligned}
& \text { Sprat }(\mathrm{kJ})=0.0096 \text { length }(\mathrm{cm})^{3.845} \\
& (\mathrm{r}=0.891, \mathrm{n}=34, \mathrm{p}<0.001) \\
& \text { Sandeel }(\mathrm{kJ})=0.0081 \text { length }(\mathrm{cm})^{3.427} \\
& (\mathrm{r}=0.965, \mathrm{n}=25, \mathrm{p}<0.001)
\end{aligned}
$$

based on fish collected from seabirds during the 1976 and 1986 to 1988 breeding seasons (Hislop et al. 1991).

\section{RESULTS}

Comparisons of estimated breeding and feeding parameters for guillemots in 2004 and earlier years are made in Table 1 . They show clearly that 2004 was an extreme year with many of the values falling well outside the $95 \%$ confidence intervals for the long-term means, and often being the most extreme values. The difference was already apparent at the start of the breeding season when, although the return rate of colour-ringed adults was only slightly depressed, a higher percentage of birds failed to breed. Qualitative observations in April and early May showed that adults spent much less time than usual at the colony during the pre-laying period (data not shown in Table 1). Systematic observations indicated that the mean date of laying was delayed by about 1 wk and fewer males than usual were present at laying. Hatching, and particularly chick rearing success were both reduced and overall breeding success, was by far the lowest recorded over the study period. In 2004 many young were seen dead on the ledges. For instance, on one broad ledge where 79 young were lost during the year, 38 dead chicks were counted on a single day. Herring gulls Larus argentatus were seen to take a few chicks but generally preferred to eat deserted eggs. Guillemots are adapted to breed at very high density (30 pairs $\mathrm{m}^{-1}$ ) and will brood, and even adopt, chicks of their neighbours (Birkhead 1978, Wanless \& Harris 1985). In contrast, in 2004 adults viciously attacked wandering chicks and in some cases killed them.

Further behavioural differences were also apparent in terms of parental activity patterns. Members of pairs spent little time together at the nest-site after a bird returned with a fish for the chick and unprecedented numbers of chicks were left unattended, indicating that adults were maximizing the amount of time away from the colony. Mean adult mass was significantly lower than the long-term average, suggesting that these birds were in poor condition. Effects were also apparent in the chicks with mass for any given wing length markedly depressed (Fig. 1) and weights of young close to leaving the colony being approximately $75 \%$ of the long-term value. We did not measure any chicks of known age in 2004 so cannot exclude the possibility that the development of the wing was also retarded. However, if this were the case, then the difference in chick weight at age would have been even greater than Fig. 1 suggests. Despite poor growth, the mean time between a chick hatching and leaving the colony was only $1 \mathrm{~d}$ longer than the long-term average,

\begin{tabular}{|c|c|c|c|c|c|}
\hline & \multicolumn{2}{|c|}{$2004-$} & \multirow[b]{2}{*}{$\mathrm{n}$} & - 1981-2003 & \multirow[b]{2}{*}{$95 \% \mathrm{CI}$} \\
\hline & $\mathrm{n}$ & Mean & & Mean & \\
\hline Adults alive in 2003 returning in 2004 (\%) & 374 & 90.1 & 18 & 92.1 & $90.6-93.5$ \\
\hline Experienced adults not breeding (\%) & 337 & 9.4 & 21 & 6.6 & $6.0-7.2$ \\
\hline Male present when female laid (\%) & 45 & $7^{*}$ & 18 & 86 & $81-91$ \\
\hline First egg date in the colony & 983 & 24 April & 22 & 22 April & 20-24 April \\
\hline Mean laying date of earliest subcolony & 301 & 10 May & 22 & 03 May & 2-5 May \\
\hline Hatching success (\%) & 983 & $77^{*}$ & 22 & 84 & $82-85$ \\
\hline Young leaving colony (\%) & 758 & $66^{*}$ & 22 & 92 & $90-94$ \\
\hline Young reared pair laying ${ }^{-1}$ & 983 & $0.51^{*}$ & 221 & 0.77 & $0.74-0.80$ \\
\hline \% sandeel in diet (mass) & 1341 & $1^{*}$ & 23 & 52 & $40-65$ \\
\hline \% sandeel in diet (n) & 1341 & $1.6^{*}$ & 23 & 58.7 & $47-71$ \\
\hline \% sprat in diet (n) & 1341 & 97.9* & 23 & 39.4 & $28-51$ \\
\hline Calculated weight of fish fed to chick (g) & 1341 & 6.3 & 22 & 6.6 & $4.2-10.2$ \\
\hline Feeds to chicks d ${ }^{-1}$ & $4 \mathrm{~d}$ & 4.5 & $23 \mathrm{~d}$ & 4.4 & $4.1-4.7$ \\
\hline Calculated daily intake of chick (g) & $4 \mathrm{~d}$ & 28.3 & $22 \mathrm{~d}$ & 27.8 & $18.2-36.3$ \\
\hline Change-over time after a feed (min) & 207 & $3.5^{*}$ & 16 & 19.9 & $13-26.7$ \\
\hline Days between hatching and leaving the colony & 304 & 22.8 & 17 & 21.8 & $21.4-22.3$ \\
\hline Weight of adult with chick (g) & 72 & 921 & 20 & 943 & $930-955$ \\
\hline Weight of chicks near fledging age (g) & 41 & $189^{*}$ & 22 & 249 & $242-256$ \\
\hline Both adults with chick at mid-day (\%) & 27 & $0.6^{*}$ & 17 & 16.7 & $10.9-23$ \\
\hline Chick alone at mid-day (\%) & 27 & $10.5^{*}$ & 17 & $<0.01$ & $0-<0.1$ \\
\hline Time female present after chick leaves (d) & 20 & $4.3^{*}$ & 12 & 13.2 & $11.4-15$ \\
\hline
\end{tabular}

Table 1. Uria aalge. Breeding and feeding parameters of common guillemots on the Isle of May in 2004 compared to data collected in an identical manner in 1981 to 2003. Numbers in bold indicate where values for 2004 fell outside the $95 \%$ CI for the previous years. ${ }^{*}$ Value was outside the previous range and represents the most extreme value recorded 


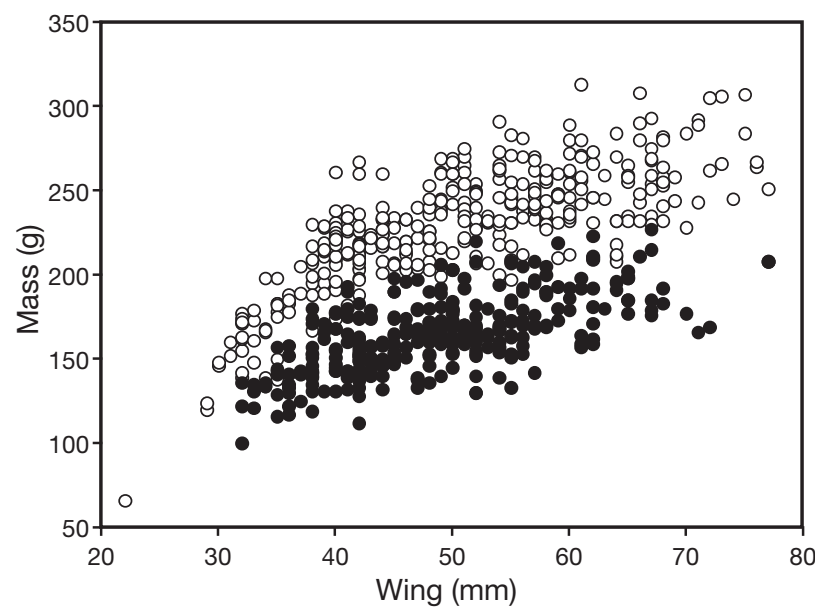

Fig. 1. Uria aalge. Lower mass (g) at age (indicated by wing length) of common guillemot chicks in 2004 (g) $(\bullet, \mathrm{n}=297)$ compared to previous years at this colony (1994 used for comparison, $\mathrm{O}, \mathrm{n}=320$ )

suggesting that the males took their chicks to sea when they were underweight rather than waiting for them to gain additional mass. Typically, guillemot chicks fledge during the late evening and night but in 2004 this pattern was disrupted with many departures occurring in the afternoon and early evening. During the post-fledging period the female usually attends the breeding site for a further 11 to $15 \mathrm{~d}$ but in 2004 the mean number of days was reduced to 4 .

The dramatic changes in reproductive output, phenology and parental activity recorded for guillemots on the Isle of May in 2004 were all consistent with a decrease in food availability. Of the 1341 fish recorded fed to chicks in 2004, the vast majority $(1313 ; 97.9 \%)$ were sprats, $21(1.6 \%)$ were sandeels and the remaining $7(0.5 \%)$ were unidentified Gadidae. The majority of sandeels and sprats were approximately 12 and $9.5 \mathrm{~cm}$ long respectively with calculated wet weights, using published weight-length relationships, of 5.7 and $6.3 \mathrm{~g}$ respectively (Harris \& Hislop 1978). The

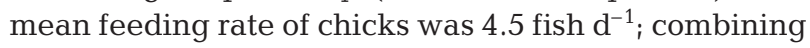
this value with the observed prey species and sizes produced a calculated daily intake of $28.1 \mathrm{~g}$, a value slightly higher than the long-term average.

Thus, taken at face value, the observed feeding frequency, diet composition, and the calculated food intakes were at odds with the depressed chick growth, poor condition at fledging and high mortality of young guillemots recorded in 2004. However, this paradox was resolved when the energy content of fish was analysed and revealed that values for both sandeels and sprats were of exceptionally low. The mean values for 20 sprat and 19 sandeels were $7.6 \pm 0.7 \mathrm{~kJ} \mathrm{~g}^{-1}$ and $5.8 \pm 0.5 \mathrm{~kJ} \mathrm{~g}^{-1}$ dry weight, respectively. Individual values are given in Table 2. Although as expected, the

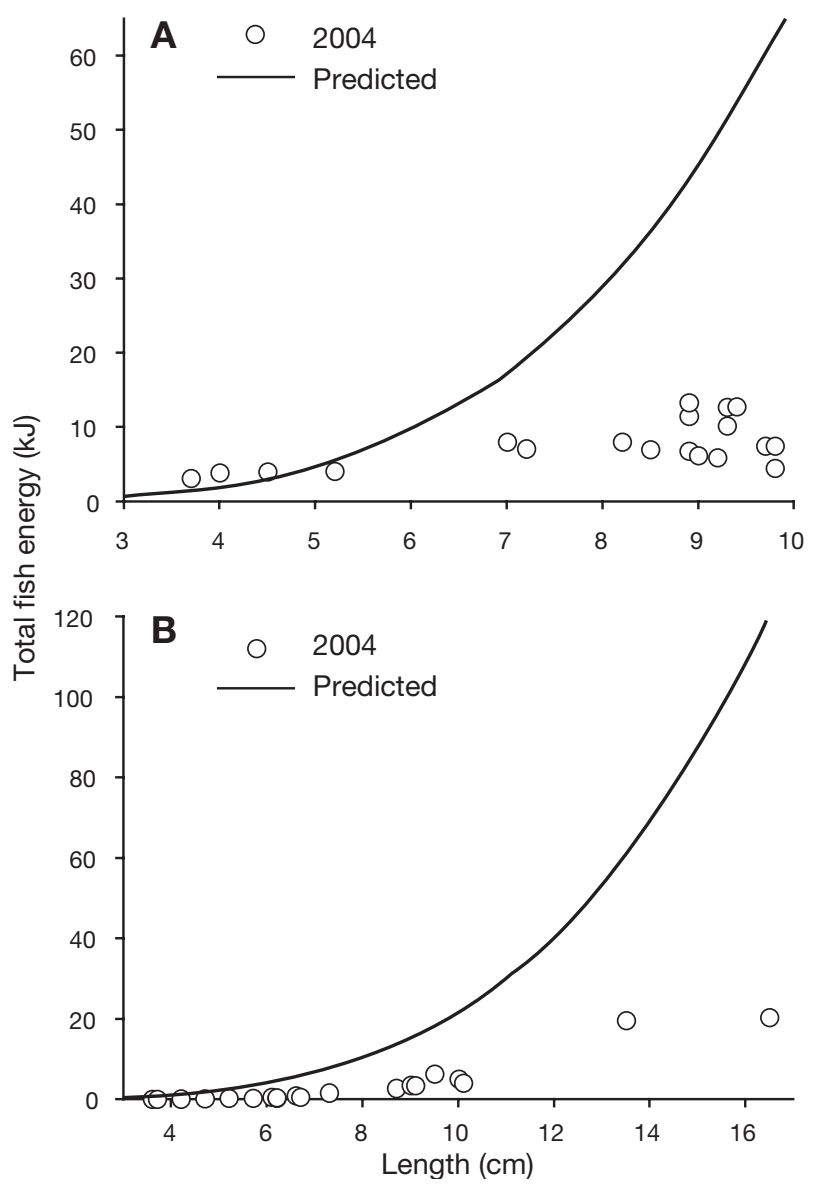

Fig. 2. Sprattus sprattus and Ammodytes marinus. Total measured energy content (kJ) of (A) sprats and (B) sandeels collected from seabirds on the Isle of May in 2004 (O) compared to those predicted from regressions based on earlier years (plotted curve; see text)

total energy value of sandeels and sprats increased with length, energy content, particularly of the larger fish, was markedly lower than previous measurements of fish from this colony (Fig. 2). For example, the mean energy value of a sprat 9 to $10 \mathrm{~cm}$ long was $11.9 \pm$ SE $2.2 \mathrm{~kJ}(\mathrm{n}=12)$, only $22 \%$ of the predicted value $(55.0 \mathrm{~kJ})$, while the mean value of a sandeel 9.5 to $10.0 \mathrm{~cm}$ long was $5.2 \pm 0.7 \mathrm{~kJ}(\mathrm{n}=3), 26 \%$ of the predicted value of $20.2 \mathrm{~kJ}$. Substituting these results into the calculation of the daily energy intake indicated that, on average, guillemot chicks in 2004 received $53 \mathrm{~kJ} \mathrm{~d}^{-1}$, less than a quarter of the predicted $245 \mathrm{~kJ} \mathrm{~d}^{-1}$.

\section{DISCUSSION}

Comparisons of the results for 2004 with the longterm data on breeding performance clearly indicated that overall it was the worst breeding season for guillemots since detailed records on the Isle of May began in 
Table 2. Sprattus sprattus and Ammodytes marinus. Energy values based on body composition of individual sprats and lesser sandeels collected from seabirds on the Isle of May in 2004

\begin{tabular}{|c|c|c|c|c|c|}
\hline $\begin{array}{l}\text { Length } \\
(\mathrm{mm})\end{array}$ & $\begin{array}{l}\text { Dry mass } \\
(\mathrm{g})\end{array}$ & $\begin{array}{l}\text { Fat } \\
(\mathrm{g})\end{array}$ & $\begin{array}{l}\text { Protein } \\
\text { (g) }\end{array}$ & $\begin{array}{c}\text { Total fish } \\
\text { energy }(\mathrm{kJ})\end{array}$ & $\begin{array}{c}\text { Energy density } \\
\left(\mathrm{kJ} \mathrm{g}^{-1} \text { dry wt }\right)\end{array}$ \\
\hline \multicolumn{6}{|l|}{ Sprat } \\
\hline 37 & 0.0519 & 0.0000 & 0.0067 & 0.16 & 3.1 \\
\hline 40 & 0.0634 & 0.0017 & 0.0076 & 0.25 & 3.9 \\
\hline 45 & 0.0914 & 0.0018 & 0.0124 & 0.37 & 4.0 \\
\hline 52 & 0.1437 & 0.0017 & 0.0220 & 0.59 & 4.1 \\
\hline 70 & 0.5632 & 0.0760 & 0.0620 & 4.48 & 8.0 \\
\hline 72 & 0.7583 & 0.0836 & 0.0876 & 5.39 & 7.1 \\
\hline 82 & 0.6752 & 0.0855 & 0.0856 & 5.41 & 8.0 \\
\hline 85 & 0.9682 & 0.0943 & 0.1286 & 6.78 & 7.0 \\
\hline 89 & 1.1864 & 0.1251 & 0.1317 & 8.08 & 6.8 \\
\hline 89 & 1.1137 & 0.2527 & 0.1182 & 12.81 & 11.5 \\
\hline 89 & 1.2949 & 0.3566 & 0.1306 & 17.22 & 13.3 \\
\hline 90 & 1.0217 & 0.0737 & 0.1446 & 6.34 & 6.2 \\
\hline 92 & 1.1238 & 0.0758 & 0.1536 & 6.64 & 5.9 \\
\hline 93 & 1.3077 & 0.2524 & 0.1397 & 13.31 & 10.2 \\
\hline 93 & 1.6066 & 0.4218 & 0.1540 & 20.35 & 12.7 \\
\hline 94 & 1.6462 & 0.4280 & 0.1737 & 21.07 & 12.8 \\
\hline 97 & 1.3801 & 0.1583 & 0.1718 & 10.34 & 7.5 \\
\hline 98 & 1.5551 & 0.1842 & 0.1827 & 11.62 & 7.5 \\
\hline 98 & 1.2324 & 0.0293 & 0.1855 & 5.56 & 4.5 \\
\hline \multicolumn{6}{|l|}{ Sandeel } \\
\hline 36 & 0.0213 & 0.0000 & 0.0034 & 0.08 & 3.8 \\
\hline 37 & 0.0237 & 0.0000 & 0.0036 & 0.09 & 3.6 \\
\hline 42 & 0.0264 & 0.0000 & 0.0054 & 0.13 & 4.8 \\
\hline 47 & 0.0532 & 0.0005 & 0.0066 & 0.18 & 3.3 \\
\hline 52 & 0.0732 & 0.0016 & 0.0102 & 0.31 & 4.2 \\
\hline 57 & 0.0794 & 0.0027 & 0.0093 & 0.33 & 4.1 \\
\hline 61 & 0.1346 & 0.0057 & 0.0166 & 0.62 & 4.6 \\
\hline 62 & 0.0751 & 0.0006 & 0.0115 & 0.30 & 4.0 \\
\hline 62 & 0.1145 & 0.0023 & 0.0138 & 0.42 & 3.6 \\
\hline 66 & 0.1745 & 0.0111 & 0.0201 & 0.92 & 5.2 \\
\hline 67 & 0.1380 & 0.0048 & 0.0170 & 0.59 & 4.3 \\
\hline 73 & 0.2129 & 0.0248 & 0.0276 & 1.64 & 7.7 \\
\hline 87 & 0.4146 & 0.0381 & 0.0535 & 2.78 & 6.7 \\
\hline 90 & 0.5211 & 0.0542 & 0.0580 & 3.52 & 6.8 \\
\hline 91 & 0.4795 & 0.0492 & 0.0628 & 3.44 & 7.2 \\
\hline 95 & 0.5479 & 0.1252 & 0.0589 & 6.35 & 11.6 \\
\hline 100 & 0.6146 & 0.0837 & 0.0757 & 5.11 & 8.3 \\
\hline 101 & 0.6132 & 0.0542 & 0.0818 & 4.08 & 6.7 \\
\hline 135 & 1.9113 & 0.3832 & 0.1896 & 19.67 & 10.3 \\
\hline 165 & 3.3690 & 0.2739 & 0.4016 & 20.36 & 6.0 \\
\hline
\end{tabular}

1981. Breeding was late and unproductive, the chicks that were reared were underweight and adults reduced the time spent at the colony to a minimum and were also underweight. Previous studies of common guillemot, pigeon guillemot Cepphus columba and northern gannet Morus bassanus using VHF and satellite telemetry have demonstrated that individuals spending less time at the colony also spend more time actively foraging (Monaghan et al. 1994, Hamer et al. 2000, Litzow \& Piatt 2003). Guillemots on the Isle of May typically feed their young on adult (1+ group) sandeels but in 2004 sprats made up $98 \%$ of the prey delivered. Although we have no independent assessment of food availability, all the evidence suggests that birds were having extreme difficulty finding large sandeels during the chick rearing period. Concurrent studies showed that other seabird species that could find suitable alternative prey did so (Harris et al. 2005). Thus, European shags Phalacrocorax aristotelis utilized a variety of bottom-living species such as longspined sea-scorpion Myxocephalus scorpius, butterfish Pholis gunellus and small unidentifiable Gadidae, while razorbills Alca torda and Atlantic puffins brought in large numbers of small Clupeidae, apparently most, if not all, sprats. Although the bulk of the food of young black-legged kittiwakes was still sandeels, clupeids and transparent goby Aphia minuta were also recorded. All these seabird species, which on the Isle of May normally rely on sandeels to feed their chicks, had unusually low breeding success in 2004.

When feeding conditions are good, guillemots with chicks spend a considerable proportion of the day alongside their mates at the colony. However, as conditions become less favourable the amount of time members of a pair spend together at the site is reduced to a minimum. This flexibility in activity budgets enables adults to maintain the rate of prey delivery to the chick (Burger \& Piatt 1990). The high incidence of neglected guillemot chicks recorded on the Isle of May in 2004 suggested that adults had exhausted their time buffer against food shortage. This increase in foraging effort was associated with reduced adult body condition and unattended chicks were potentially more vulnerable to predation and attacks from conspecifics, and their thermoregulatory costs were also presumably higher since chicks were not brooded continuously.

Comparison of chick provisioning rates in 2004 with those from previous years indicates that by leaving chicks unattended adults were able to maintain a normal rate for the Isle of May and other colonies (Ainley et al. 2002). Furthermore, the prey items brought back also seemed adequate to maintain a food intake comparable to previous years when breeding success was high and chicks left the colony in better condition. However, measurements 
of calorific densities in 2004 (7.6 and $5.8 \mathrm{~kJ} \mathrm{~g}^{-1}$ for sprat and sandeel respectively) were less than $25 \%$ of those expected from previous samples from the Isle of May and fishery samples in the North Sea during June and July (Hislop et al. 1991). The 2004 values were also far lower than those of 23 fish species sampled from seabirds in Alaska and Labrador (range 14.8 to $28.3 \mathrm{~kJ} \mathrm{~g}^{-1}$; Birkhead \& Nettleship 1987, Anthony \& Roby 1997, van Pelt et al. 1997) and 39 species sampled by trawling and trapping in Alaska (range 14.3 to $27.2 \mathrm{~kJ} \mathrm{~g}^{-1}$; Anthony et al. 2000) When these year-specific energy values were used to calculate daily energy intakes, guillemot chicks in 2004 were estimated to have received only about $53 \mathrm{~kJ} \mathrm{~d}^{-1}$, which compares with values of 295 to $386 \mathrm{~kJ} \mathrm{~d}^{-1}$ for chicks on the Isle of May in 1982 to 1984, and 296 and $336 \mathrm{~kJ} \mathrm{~d}^{-1}$ for 2 seasons in Newfoundland where energy values of fish taken from seabirds were measured directly (Harris \& Wanless 1985, Birkhead \& Nettleship 1987). Given these very low values it is therefore not surprising that the growth of guillemot chicks on the Isle of May in 2004 was greatly depressed and breeding success extremely poor.

Guillemot breeding failures of the magnitude and spatial scale recorded in the North Sea in 2004 are unprecedented (Mavor et al. 2005). However, such events do occur regularly in the Pacific where they have been linked to climate variability impacting on prey abundance cascading through to upper trophic levels (Sydeman et al. 2001). Similar observations for a range of marine birds and mammals have given support to the 'junk food' hypothesis which states that the energy density of low-lipid prey is inadequate to meet the energetic demands of breeding, even if such prey are abundant (Piatt \& Anderson 1996, Merrick et al. 1997, Rosen \& Trites 2000, Litzow et al. 2002). Typically the lipid-rich prey needed for successful breeding are pelagic schooling fish species and the low-lipid prey are demersal species. Our results from the Isle of May also indicate that guillemot breeding failure in 2004 was associated with lipid-poor prey. However, this was not due to a switch to a demersal species but rather that the usual pelagic schooling prey fish had a very low energy content. Captive feeding experiments involving seabirds and seals also provide support for the junk food hypothesis and indicate that young fed on low-lipid diets show reduced growth, reduced lipid reserves and elevated levels of corticosterone stress hormones (Kitaysky et al. 1999, Rosen \& Tries 2000). We did not collect any physiological data for guillemot chicks in 2004 but it is possible that such effects would have been apparent. The junk food hypothesis has predominantly been considered in the context of perturbations in food web dynamics in the Pacific, particularly Alaska. However, effects are now becoming evident in the Atlantic; e.g. Davoren \& Montevecchi (2003) recently found a decline in the body condition of guillemot chicks at a colony in Newfoundland. This was associated with a reduction in the energy value of individual prey items due to parents delivering smaller capelin Mallotus villosus. Similarly Österblom et al. (2001) found a long-term decline in the mass of guillemot chicks leaving a colony in the Baltic which coincided with a decline in condition (measured as mean weight at age) of sprat, the preferred prey. We fully concur with the view expressed by the latter authors that more attention needs to be given to the energy value, rather than just the size, of fish eaten by seabirds.

The reason(s) behind the very low energy values of lesser sandeels and sprats in 2004 is currently unknown but the fact that both species are planktivorous suggests change in the abundance or distribution of the plankton. Dramatic changes in species composition and phenology of phyto- and zooplankton in the North Sea have occurred in recent years (Beaugrand et al. 2002, Beaugrand 2004). These changes are likely to have affected higher trophic levels through e.g. a mismatch of food requirements and prey availability (Edwards \& Richardson 2004). For example, failing recruitment in cod Gadus morhua has been linked to a lack of suitable zooplankton prey for larvae at the right time (Beaugrand et al. 2003). It therefore seems likely that changes in the plankton community could also be responsible for the observed decline in size and quality of guillemot prey.

Furness \& Tasker (2000) developed a system to rank the sensitivity of North Sea seabirds to reductions in sandeel availability. Ranks were based on scores of a series of measures, e.g. body size, foraging methods etc. In this system the guillemot emerged as being one of the least sensitive species. However, the authors did not consider the method of provisioning the chicks or the consequences of prey size or energy density decreasing in their assessments. The emerging evidence for a decline in sandeel size (Wanless et al. 2004), and possibly also sprat size, combined with a reduction in energy value may require a revision of this ranking system that will result in an increased sensitivity score for single-prey loaders, such as the guillemot.

We have highlighted how a lower energy content of sandeels may be impacting on the reproductive output of top predators. However, there are also economic consequences of these findings since the industrial sandeel fishery is currently the largest single species fishery in the North Sea (ICES 2003). A reduction in fat, and hence oil, content of the fish will presumably also reduce the value of the catch for processing for fishmeal and/or oil. 
Acknowledgements. We thank the many people who helped with fieldwork over the years and Scottish Natural Heritage for allowing us to work on the Isle of May National Nature Reserve. M. Frederiksen, F. Daunt, S. Lewis, W. Sydeman and 4 anonymous referees greatly improved the manuscript with their comments. Part of the fieldwork was carried out with funding from the Joint Nature Conservation Committee's integrated seabird monitoring programme.

\section{LITERATURE CITED}

Ainley DG, Nettleship DN, Carter HR, Storey AE (2002) Common murre (Uria aalge). In: Poole A, Gill F (eds) The birds of North America. The Birds of North America Inc., Philadelphia, PA

Anthony JA, Roby DD (1997) Variation in lipid content of forage fished and its effect on energy provisioning rates to seabird nestlings: forage fishes in marine ecosystems. Proceedings of the International Symposium on the role of forage fishes in marine ecosystems. Alaska Sea Grant College Program Report No. 97-01:725-729, Alaska Sea Grant, Fairbanks, AK

Anthony JA, Roby DD, Turco KR (2000) Lipid content and energy density of forage fishes from the northern Gulf of Alaska. J Exp Mar Biol Ecol 248:53-78

Beaugrand G (2004) The North Sea regime shift: evidence, causes, mechanisms and consequences. Prog Oceanogr 60:245-262

Beaugrand G, Reid PC, Ibañez F, Lindley JA, Edwards M (2002) Reorganization of North Atlantic marine copepod biodiversity and climate. Science 296:1692-1694

Beaugrand G, Brander KM, Lindley JA, Souissi S, Reid PC (2003) Plankton effect on cod recruitment in the North Sea. Nature 426:661-664

Birkhead TR (1978) Behavioural adaptations to high density nesting in the common guillemot Uria aalge. Anim Behav 26:321-331

Birkhead TR, Nettleship DN (1987) Ecological relationships between common murres, Uria aalge, and thick-billed murres, Uria lomvia, at the Gannet Islands, Labrador. III. Feeding ecology of young. Can J Zool 65:1638-1649

Burger AE, Piatt JF (1990) Flexible time budgets in breeding Common murres as buffers against variable prey abundance. Stud Avian Biol 14:71-83

Crisp DJ (1971) Energy flow measurements. In: Holme NA, McIntyre AD (eds) IBP handbook, Vol 16. Blackwell Scientific Publications, Oxford, p 197-279

Davoren, GK, Montevecchi, WA (2003) Signals from seabirds indicate changing biology of capelin stocks. Mar Ecol Prog Ser 258:253-261

Edwards M, Richardson AJ (2004) Impact of climate change on marine pelagic phenology and trophic mismatch. Nature 430:881-884

Furness RW, Tasker ML (2000) Seabird-fishery interactions: quantifying the sensitivity of seabirds to reductions in sandeel abundance, and identification of key areas for sensitive seabirds in the North Sea. Mar Ecol Prog Ser 202:253-264

Hamer KC, Phillips RA, Wanless S, Harris MP, Wood AG (2000) Foraging ranges, diets and feeding locations of gannets Morus bassanus in the North Sea: evidence from satellite telemetry. Mar Ecol Prog Ser 200:257-264

Harris MP, Hislop JRG (1978) The food of young puffins (Fratercula arctica). J Zool (Lond) 185:213-239

Harris MP, Wanless S (1985) Fish fed to young guillemots,
Uria aalge, and used in display on the Isle of May, Scotland. J Zool (Lond) 207:441-458

Harris MP, Wanless S (1988) The breeding biology of guillemots Uria aalge on the Isle of May over a 6-year period. Ibis 130:172-192

Harris MP, Wanless S (2003) Post-fledging occupancy of nestsites by female common murres (Uria aalge). Auk 120:75-81

Harris MP, Halley DJ, Wanless S (1992) The post-fledging survival of young guillemots Uria aalge in relation to hatching date and growth. Ibis 134:335-339

Harris MP, Wanless S, Murray S, Mackley E (2005) Isle of May seabird studies in 2004. Report No. 362. Joint Nature Conservation Committee, Peterborough

Hedgren S, Linnman A (1979) Growth of guillemot Uria aalge chicks in relation to time of hatching. Ornis Scand 10: 29-36

Hislop JRG, Harris MP, Smith JGM (1991) Variation in the calorific value and total energy content of the lesser sandeel (Ammodytes marinus) and other fish preyed on by seabirds. J Zool (Lond) 224:501-517

ICES (2003) Report of the Working Group on the assessment of demersal stocks in the North Sea and Skagerrak 2002. International Council for the Exploration of the Sea, Copenhagen

Kitasky AS, Piatt JF, Wingfield JC, Romano M (1999) The adrenocortical stress-response in black-legged kittiwake chicks in relation to dietary restrictions. J Comp Physiol B 169:303-310

Litzow MA, Piatt JF (2003) Variance in prey abundance influences time budgets of breeding seasbirds: evidence from pigeon guillemots Cepphus columba. J Avian Biol 34: $54-64$

Litzow, MA, Piat JF, Prichard AK, Roby DD (2002) Response of pigeon guillemots to variable abundance of high-lipid and low-lipid prey. Oecologia 132:286-295

Mavor RA, Parsons M, Heubeck M, Schmitt S (2004) Seabird numbers and breeding success in Britain and Ireland, 2003. Report No. 27. Joint Nature Conservation Committee, Peterborough

Mavor RA, Parsons M, Heubeck M, Schmitt S (2005) Seabird numbers and breeding success in Britain and Ireland, 2004. Report No. 29. Joint Nature Conservation Committee, Peterborough

Merrick, RL, Chumbley, MK, Byrd, GV (1997) Diet diversity of Steller sea lions (Eumetopias jubatus) and their population decline in Alaska: a potential relationship. Can J Fish Aquat Sci 54:1342-1348

Mitchell PI, Newton SF, Ratcliffe N, Dunn TE (2004) Seabird populations of Britain and Ireland: results of the seabird 2000 census (1998-2002). T \& AD Poyser, London

Monaghan P, Uttley JD, Burns MD (1992) Effect of changes in food availability on reproductive effort in Arctic terns Sterna paradisaea. Ardea 80:71-81

Monaghan P, Walton P, Wanless S, Uttley JD, Burns MD (1994) Effects of prey abundance on the foraging behaviour, diving efficiency and time allocation of breeding guillemots Uria aalge. Ibis 136:214-222

Montevecchi WA, Piatt JF (1987) Dehydration of seabird prey during transport to the colony: effects on wet weight energy densities. Can J Zool 65:2822-2824

Österblom H, Bignert A, Fransson T, Olsson O (2001) A decrease in fledging body mass in common guillemot Uria aalge chicks in the Baltic Sea. Mar Ecol Prog Ser 224: 305-309

Pearson TH (1968) The feeding biology of seabird species breeding on the Farne Islands, Northumberland. J Anim Ecol 37:521-552 
Piatt, JF, Anderson, P (1996) Response of common murres to the Exxon Valdez oil spill and long-term changes in the Gulf of Alaska marine ecosystem. Am Fish Soc Symp 18:720-737

Reynolds DS, Kunz TH (2001) Standard methods for destructive body composition analysis. In: Speakman JR (ed) Body composition analysis of animals: a handbook of nondestructive methods. Cambridge University Press, Cambridge, p 39-55

Rosen DAS, Trites AW (2000) Pollock and the decline of Steller sea lions: testing the junk-food hypothesis. Can J Zool 78:1243-1250

Sydeman WJ, Hester MM, Thayer JA, Gress F, Paige M, Buffa J (2001) Climate change, reproductive performance and diet composition of marine birds in the southern California

Editorial responsibility: Otto Kinne (Editor-in-Chief), Oldendorf/Luhe, Germany
Current system, 1969-1997. Prog Oceanogr 49:309-329 van Pelt TI, Piatt JF, Lance BK, Roby DD (1997) Proximate composition and energy density of some North Pacific forage fishes. Comp Biochem Physiol 118A:1393-1398

Wanless S, Harris MP (1985) Two cases of guillemots Uria aalge helping to rear neighbours' chicks on the Isle of May. Seabird 8:5-8

Wanless S, Wright PJ, Harris MP, Elston DA (2004) Evidence for decrease in size of lesser sandeels Ammodytes marinus in a North Sea aggregation over a 30-yr period. Mar Ecol Prog Ser 279:237-246

Wright PJ (1996) Is there a conflict between sandeel fisheries and seabirds? A case study at Shetland. In: Greenstreet SPR, Tasker ML (eds) Aquatic predators and their prey. Fishing News Books, Blackwell Science, Oxford, p 154-165

Submitted: February 22, 2005; Accepted: May 3, 2005 Proofs received from author(s): June 3, 2005 